\title{
Vanadium Oxide/Graphene Nanoplatelet as a Cathode Material for Mg-Ion Battery
}

\author{
E. Sheha1, M. H. Makled', Walaa M. Nouman'1, A. Bassyouni ${ }^{1}$, S. Yaghmour ${ }^{2}$, S. Abo-Elhassan ${ }^{1}$ \\ ${ }^{1}$ Physics Department, Faculty of Science, Benha University, Benha, Egypt \\ ${ }^{2}$ Physics Department, Faculty of Science, University of Jeddah Branch, Jeddah, KSA \\ Email: islam.shihah@fsc.bu.edu.eg
}

How to cite this paper: Sheha, E., Makled, M.H., Nouman, W.M., Bassyouni, A., Yaghmour, S. and Abo-Elhassan, S. (2016) Vanadium Oxide/Graphene Nanoplatelet as a Cathode Material for Mg-Ion Battery. Graphene, 5, 178-188.

http://dx.doi.org/10.4236/graphene.2016.54015

Received: September 16, 2016

Accepted: October 25, 2016

Published: October 28, 2016

Copyright $\odot 2016$ by authors and Scientific Research Publishing Inc. This work is licensed under the Creative Commons Attribution International License (CC BY 4.0).

http://creativecommons.org/licenses/by/4.0/

(c) (i) Open Access

\begin{abstract}
The aim of the present work is to introduce a high performance cathode for magnesium-ion batteries. A simple ball mill process is employed to synthesize $\left(\mathrm{V}_{2} \mathrm{O}_{5}\right)_{1-\mathrm{x}}$ (Graphene Nanoplatelets (GNP)) nanocomposite, (where $\mathrm{x}=0,5,10,15,20$ and 25 wt.\% GNP). The synthesized samples are characterized using scanning electron microscope (SEM), X-ray diffraction (XRD) technique, impedance spectroscopy, cyclic voltammetry and charge-discharge test. The maximum conductivity of the investigated samples was found to be $6 \times 10^{-1} \mathrm{~S} / \mathrm{cm}$ for optimum composite film $(25 \mathrm{wt} \%$ GNP) at room temperature. Room temperature rechargeable magnesium batteries are constructed from $\mathrm{Mg}$ as anode material, $\left(\mathrm{V}_{2} \mathrm{O}_{5}\right)_{1-\mathrm{x}}(\mathrm{GNP})_{\mathrm{x}}$ as a cathode material and the simple non-aqueous electrolyte based $\mathrm{MgNO}_{3}{ }_{6} \mathrm{H}_{2} \mathrm{O} . \mathrm{Mg} / \mathrm{V}_{2} \mathrm{O}_{5}$ cells employing as-prepared electrolyte exhibit initial discharge capacity $\sim 100 \mathrm{mAhg}^{-1}$ while $\mathrm{Mg} /\left(\mathrm{V}_{2} \mathrm{O}_{5} / \mathrm{GNP}(\mathrm{x}=25 \mathrm{t} . \%)\right)$ cathode produces a lower initial capacity of $\sim 90$ $\mathrm{mAhg}^{-1}$. The high initial discharge capacity of $\mathrm{V}_{2} \mathrm{O}_{5}$ can be attributed to the presence of a large (001) interlayer spacing ( $11.53 \AA$ ) for facile $\mathrm{Mg}^{+}$insertion/extraction.
\end{abstract}

\section{Keywords}

Magnesium Batteries, Vanadium Oxide, Graphene, Conductivity

\section{Introduction}

Costly Cheveral phase $\mathrm{Mo}_{6} \mathrm{~S}_{8}$ cathode, and complicated electrolyte based $\mathrm{Mg}$ $\left[\mathrm{ALCL}_{2} \mathrm{BuET}\right]_{2} /$ tetrahydofurane (volatile) are traditional materials in early rechargeable magnesium batteries, although, these batteries suffer from low voltage, low energy density, kinetic sluggish of $\mathrm{Mg}^{+2}$ insertion/extraction [1] [2] [3] [4]. Various cathode materials for magnesium battery have been suggested in recent years, such as $\mathrm{TiS}_{2}$ nanotubes [5], $\mathrm{MoS}_{2}$ [6], $\mathrm{GeO}_{2}$ [7], $\mathrm{TiS}_{3}$ [1], $\mathrm{V}_{2} \mathrm{O}_{5}$ [8] and $\mathrm{MnO}_{2}$ [9]. Vanadium pentaoxide $\left(\mathrm{V}_{2} \mathrm{O}_{5}\right)$ 
is a semiconductor material $\left(\mathrm{E}_{\mathrm{g}}=2.4 \mathrm{eV}\right)$, where tuning of fermi level due to ion insertion is expected. The intercalation reaction of $\mathrm{Mg}$ in $\mathrm{V}_{2} \mathrm{O}_{5}$ can be written as follows: ${ }_{x} \mathrm{Mg}+\mathrm{V}_{2} \mathrm{O}_{5} \leftrightarrow \mathrm{Mg}_{x}+\mathrm{V}_{2} \mathrm{O}_{5}^{-}$. During this reaction the vanadium atoms are partially reduced from a $\mathrm{V}^{5+}$ to a $\mathrm{V}^{+4}$ formal oxidation state [10]. $\mathrm{V}_{2} \mathrm{O}_{5}$ is belonging to the layered transition metal oxides which possess the ability to structural deformations during the insertion of $\mathrm{Mg}^{+2}$ or other bivalent ions. The superior electrochemical performances of $\mathrm{V}_{2} \mathrm{O}_{5}$ could be ascribed to the unique structure revealing the presence of a large (001) crystal planes interlayer spacing $(\sim 11.53 \AA$ ), which provide large interlayer spacing for facile ion insertion/extraction [11] [12] [13]. $\mathrm{V}_{2} \mathrm{O}_{5}$ has been studied very intensively as a cathode material for Li-ion batteries [14]. Because the ionic radii of $\mathrm{Li}^{+}$and $\mathrm{Mg}^{2+}$ are comparable in magnitude, 68 and $65 \mathrm{pm}$, respectively, the replacement of $\mathrm{Li}^{+}$ions by $\mathrm{Mg}^{2+}$ ions in insertion compounds is possible. On the other hand, although the electrochemical performance of $\mathrm{V}_{2} \mathrm{O}_{5}$ has shown great improvement, it suffers from its poor electronic conductivity, which may lead to both of poor capacity and the cyclic ability of $\mathrm{V}_{2} \mathrm{O}_{5}$ electrodes. Graphene nanoplatelets represent a new class of carbon nanoparticles with multifunctional properties. Graphene nanoplatelet addition can provide barrier properties, while their pure graphitic composition makes them excellent electrical [15] and thermal conductors and can prevent the vanadium dissolution, and alleviate the aggregation of the particles. Since graphene, the name given to a flat monolayer of carbon atoms tightly packed into a two-dimensional (2D) honeycomb lattice, exhibits superior electrical conductivities, high surface areas and chemical tolerance intrigue, many researchers have studied the $\mathrm{V}_{2} \mathrm{O}_{5}$ /graphene cathode [16] using different preparation methods to control particle size and particle shape, aiming to improve the efficiency of rechargeable batteries. In the present work we will introduce a new rechargeable magnesium battery from electrolyte system based on reaction products of $\mathrm{MgNO}_{3}{ }_{6} \mathrm{H}_{2} \mathrm{O}$, succinonitril, tetraethylene glycol dimethyl ether solvent, and $\left(\left(\mathrm{V}_{2} \mathrm{O}_{5}\right)_{0.75} / \mathrm{GNP}_{0.25}\right)$ nanocomposite cathode. One of our important goals is to reduce the cost of the battery. So the starting materials will be from market and the ball mill process is the desirable one.

\section{Experimental}

Graphene Nanoplatelets Grade M GNP was characterized by average ( $7 \mathrm{~nm}$ thickness, $10 \mathrm{~nm}$ particle diameter, $10^{7} \mathrm{~S} / \mathrm{m}$ Electrical conductivity and surface area $\sim 120-150$ $\mathrm{m}^{2} / \mathrm{g}$ ) have been imported from XG Science company. Composites of $\mathrm{V}_{2} \mathrm{O}_{5}$ and GNP were prepared by ball milling process under 4 hours' time duration. The resulted product is designated here as $\left(\mathrm{V}_{2} \mathrm{O}_{5}\right)_{1-\mathrm{x}}(\mathrm{GNP})_{\mathrm{x}}$ composites. The morphology of the nanocompsite was examined using SEM (JOEL-JSM Model 5600). The XRD patterns of the films were taken using Rigaku diffractometer type RINT-Ultima IV/S. The diffraction system based with $\mathrm{Cu}$ tube anode with voltage $40 \mathrm{KV}$ and current $40 \mathrm{~mA}$. The current-voltage characteristics of the cathodes were carried out by means of a computer controlled 2400 Keithley electrometer. For electrochemical performance testing, working electrodes $\left(\mathrm{V}_{2} \mathrm{O}_{5}\right.$ and $\mathrm{V}_{2} \mathrm{O}_{5}$-graphene composite powder) were prepared by mixing 
85 wt.\% sample as the active material, 6 wt.\% conductive agent (carbon black, Super-P-Li), and 9 wt.\% poly-vinylidene difluoride (PVDF) binder, N-methylpyrrolidone (Alfa) was then added to produce a viscous slurry and the resultant slurry was pasted onto copper foil. The as-prepared working electrodes were then dried in a vacuum oven at $373 \mathrm{~K}$ for $2 \mathrm{~h}$. Electrochemical cells (CR2032 coin type) were assembled in room temperature and ambient pressure by using the working electrode, a separator (filter paper), $\mathrm{Mg}$ ribbon as the reference and counter electrode, and $4 \mathrm{gm} \mathrm{MgNO}_{3} \cdot 6 \mathrm{H}_{2} \mathrm{O}$ in a 2:10 (w:v) mixture of succinonitril, tetraethylene glycol dimethyl ether, respectively, as the electrolyte. Figure 1 shows the structure scheme of $\mathrm{MgNO}_{3.6} \mathrm{H}_{2} \mathrm{O}$, succinonitril and tetraethylene glycol dimethyl ether. Where $\mathrm{MgNO}_{3 \cdot 6} \mathrm{H}_{2} \mathrm{O}$ is the $\mathrm{Mg}^{+2}$ pump, tetraethylene glycol dimethyl ether is a solvent and succinonitril is a plasticizer agent to dissociate ions and improve ionic conductivity. Cyclic voltammograms (CVs) were conducted in three-electrode cell using an electrochemical instrument of CHI604E Electrochemical Workstation. The cells were charged and discharged on a multi-channel battery test system (NEWARE BTS-TC35) over the voltage range of $0-1.6 \mathrm{~V}$ versus $\mathrm{Mg} / \mathrm{Mg}^{+2}$ at constant constant current density $\sim 40 \mu \mathrm{Acm}^{-1}$.

\section{Results and Discussion}

Figures 2(a)-(c) shows SEM images for $\mathrm{V}_{2} \mathrm{O}_{5}$ and $\mathrm{V}_{2} \mathrm{O}_{5} / G N P$ nanocomposites. The graphene nanoplatlets are crumpled to a curly and wavy shape. By adding GNP nanoplatlets to $\mathrm{V}_{2} \mathrm{O}_{5}$, the later was found to be uniformly distributed in GNP and well distributed on the 2D graphene nanoplatelets, as shown in Figures 2(a)-(c). Moreover, the graphene sheets can prevent the aggregation of $\mathrm{V}_{2} \mathrm{O}_{5}$ particles to a certain extent, which can be of great benefit to electrochemical reactions. The XRD patterns of the synthesized $\left(\mathrm{V}_{2} \mathrm{O}_{5}\right)_{1-\mathrm{x}}(\mathrm{GNP})_{\mathrm{x}}$ composites (where $\mathrm{x}=0,5,10,15,20$ and $25 \%$ wt GNP) are shown in Figure 3. The XRD spectrum for $\mathrm{x}=0 \%$ indicates that the $\mathrm{V}_{2} \mathrm{O}_{5}$ composites

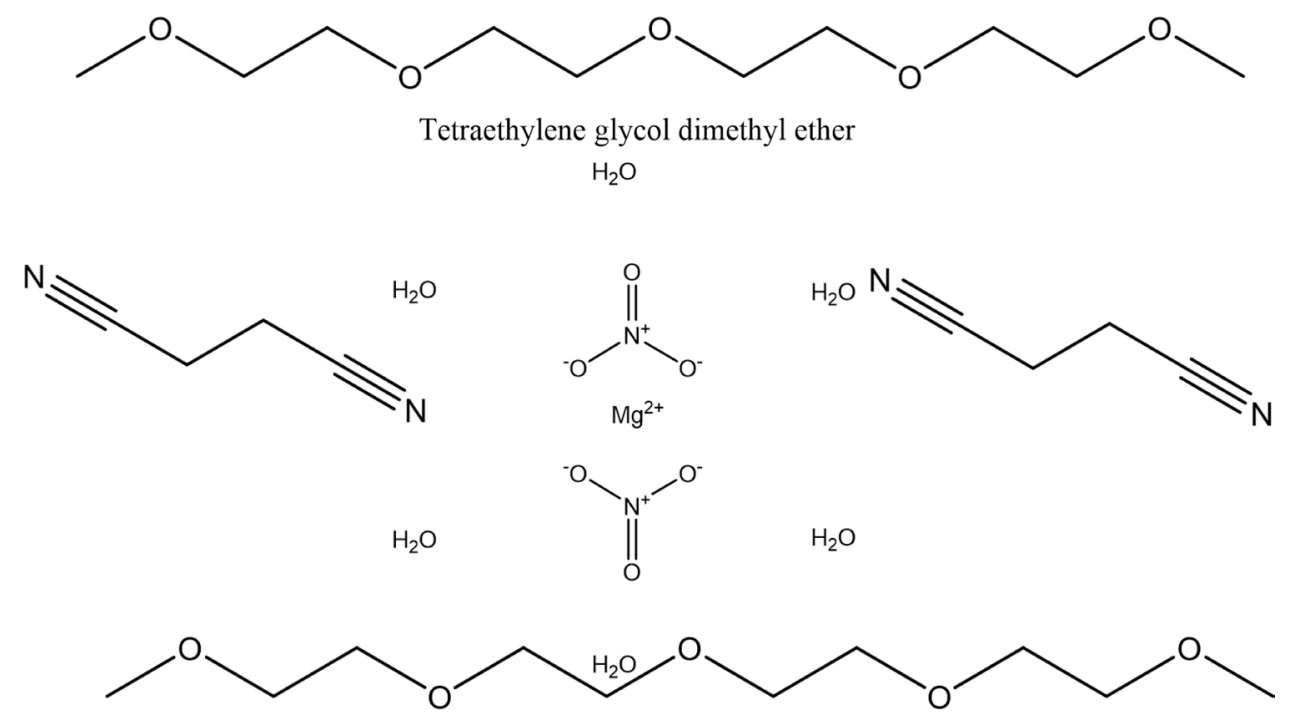

Tetraethylene glycol dimethyl ether

Figure 1. Schematic illustrates the electrolyte structure. 


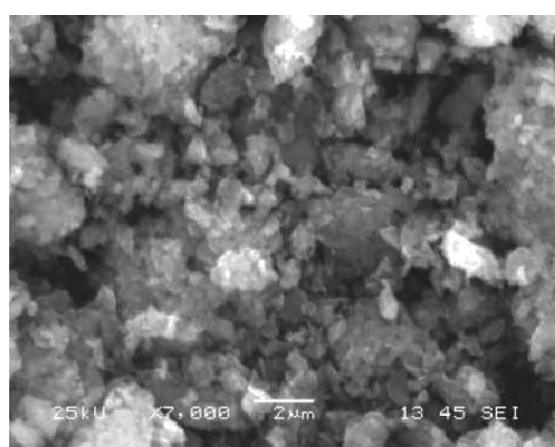

(a)

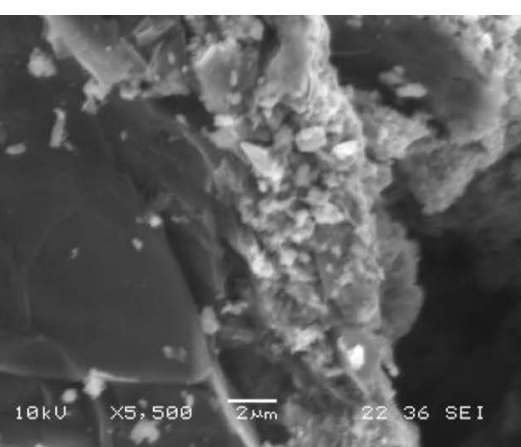

(b)

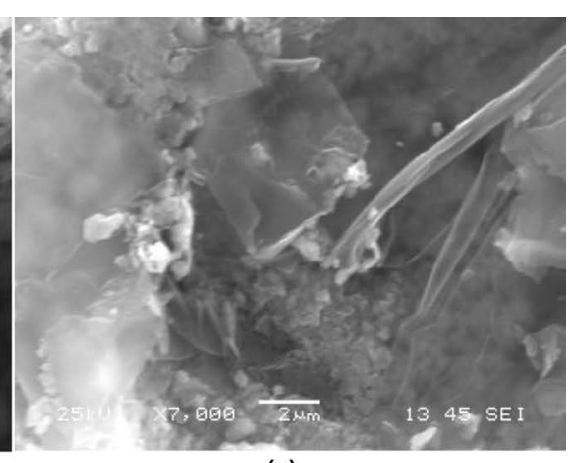

(c)

Figure 2. SEM micrographs of $\left(\mathrm{V}_{2} \mathrm{O}_{5}\right)_{1-\mathrm{x}}(\mathrm{GNP})_{\mathrm{x}}$ composites: (a) $0 \mathrm{wt} \% \mathrm{GNP}$; (b) $15 \mathrm{wt} \%$ GNP; (c) $25 \mathrm{wt} \% \mathrm{GNP}$.

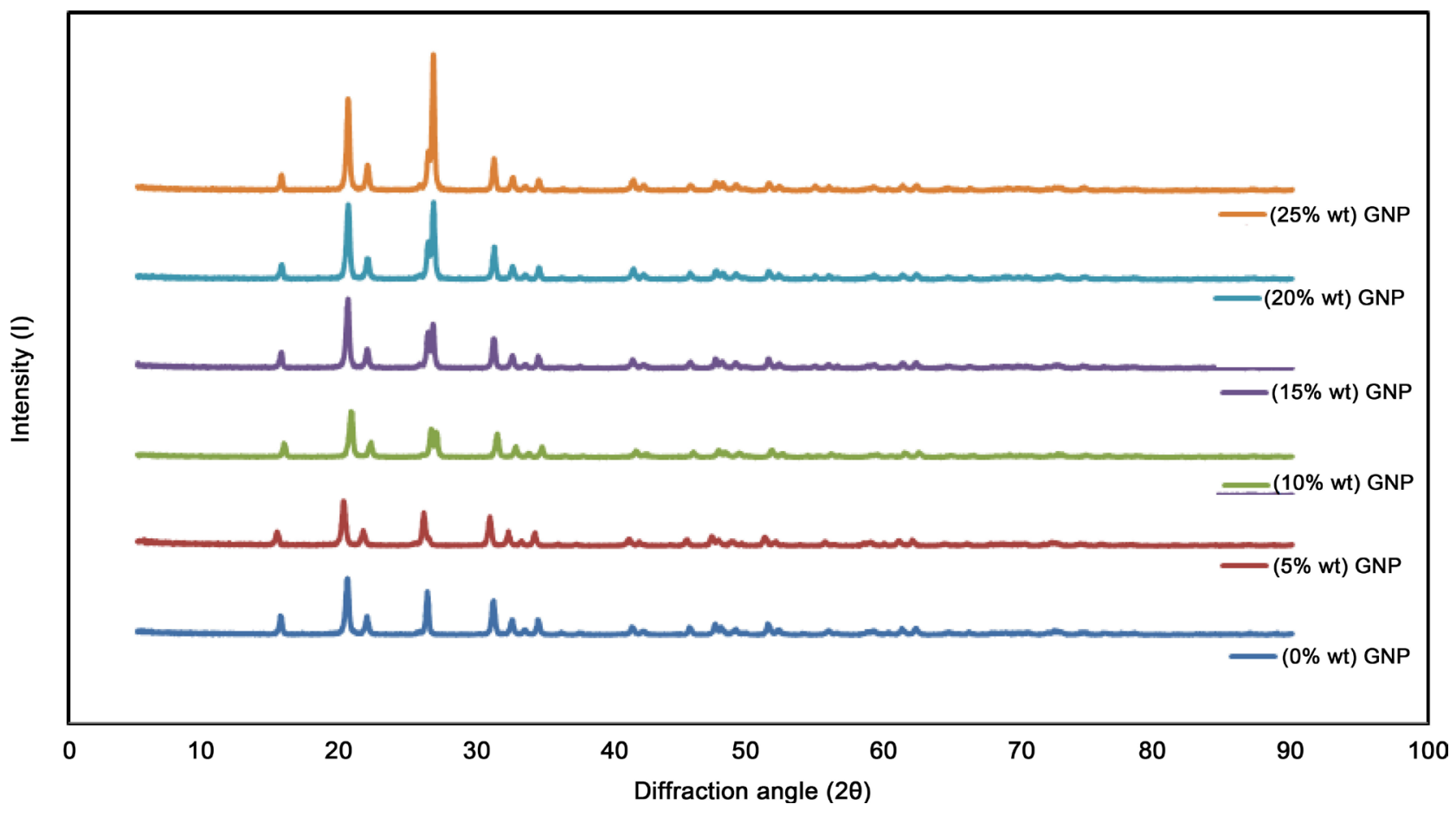

Figure 3. XRD pattern of $\left(\mathrm{V}_{2} \mathrm{O}_{5}\right)_{1-\mathrm{x}}(\mathrm{GNP})_{\mathrm{x}}$ composites.

are highly crystallized in structure and the entire diffraction peaks match well with Bragg reflections of the pure orthorhombic phase of $\mathrm{V}_{2} \mathrm{O}_{5}$ nanoparticles, which is consistent with the standard JCPDS No.41-1426 (space group Pmmn) [17] [18]. However, for $\mathrm{x}>0 \%$ an additional diffraction shoulder peak around $26.77^{\circ}$, partially overlapping with the $\mathrm{V}_{2} \mathrm{O}_{5}(110)$ peak $\left(2 \theta=26.39^{\circ}\right)$, originates from the (002) diffraction of the graphite. The intensity of the later peak increases linearly when $\mathrm{x}$ increases from 5 to $25 \%$ and its position corresponds to $\sim 31 \mathrm{~nm}$ (according to the relation: $\lambda /(2 \cdot \sin \theta, \theta=$ $26.39^{\circ}$ ) spacing between atomic planes [19]. Also, the XRD spectra show a weak peak at $54.8^{\circ}$ which corresponds to the (004) reflection of the graphite. It can be noticed that the graphite (002) peak position shifts to the lower angles for $\mathrm{x}=5 \%$ and to higher angles for $\mathrm{x}=10 \%$. This can be related to the amount of oxygen functional groups formed between the platelets of the graphite. From the XRD measurements, no additional 
phases related to structural defects can be detected, while orthorhombic $\mathrm{V}_{2} \mathrm{O}_{5}$ can be detected after ball milling of $\mathrm{V}_{2} \mathrm{O}_{5}$ and GNP. Small shift in peak positions of $\mathrm{V}_{2} \mathrm{O}_{5}$ after doping by GNP was observed which confirm change in (001) interlayer spacing. The crystallite size $(\tau)$ of the investigated samples $\left(\mathrm{V}_{2} \mathrm{O}_{5}\right)_{1-\mathrm{x}}(\mathrm{GNP})_{\mathrm{x}}$ nano-composites (where $\mathrm{x}=0,5,10,15,20$ and $25 \% \mathrm{wt}$ GNP) can be calculated using the first sphere approximation of Debye-Scherrer formula [20] $\tau=\mathrm{K} \lambda / \beta \cos \theta$, where $\mathrm{K}$ is the shape factor, $\lambda$ is the $\mathrm{X}$-ray wavelength, $\beta$ is the line broadening at half the maximum intensity in radians, and $\theta$ is the Bragg angle. Using this formula, crystallite dimensions of about 30 $\mathrm{nm}$ could be calculated from the high intense peaks. Figure 4(a), shows the current voltage $(\mathrm{I} \& \mathrm{~V})$ characteristics of $\left(\mathrm{V}_{2} \mathrm{O}_{5}\right)_{1-\mathrm{x}}(\mathrm{GNP})_{\mathrm{x}}$ nano-composite. Generally, the current increases linearly with increasing voltage obeying $\mathrm{Ohm}$ law. The dc conductivity was calculated using the equation: $\sigma_{d c}=\frac{1}{R} \times \frac{L}{A}$ [21], where $t$ is the thickness of the sample and $\mathrm{A}$ is the surface area of the sample. The value of the resistivity $R$ was measured from the slopes of the straight lines in ohmic region I $\alpha$ V Figure 4(a), The effect of graphene content on the dc conductivity $\sigma_{d c}$ of $\left(\mathrm{V}_{2} \mathrm{O}_{5}\right)_{1-\mathrm{x}}(\mathrm{GNP})_{\mathrm{x}}$ is shown in Figure 4(b). The dc conductivity of the composites exhibits insulator behavior for pure $\mathrm{V}_{2} \mathrm{O}_{5}$ recording $\sim 10 \times 10^{-6} \mathrm{~S} / \mathrm{m}$, whereas semiconductor behavior for low graphene content up to $\mathrm{x}=10 \mathrm{wt} \%$ was recorded. The electrical conductivity increased as the content of graphene was close to percolation threshold up to $\mathrm{x}=5 \mathrm{wt} \%$. Above the percolation threshold $\sigma_{d c}$ was found to increases exponentially before it reach to the saturated point $(\mathrm{x}=10 \mathrm{wt} \%)$ which may be attributed to the formation of filler network and the composites may reach to the metallic behavior. This behavior can be described according to the percolation theory as the following power relation [22],

$$
\sigma_{d c}=\sigma_{c}\left(V_{G N P}-V_{C}\right)^{t} \text { for } V_{G N P}>V_{C}
$$

where $\sigma_{c}$ is the conductivity of conducting component, $V_{G N P}$ is the volume fraction of Graphene, $V_{C}$ is the critical volume fraction or percolation threshold, and the exponent $t$ reflects the dimensionality of the system and has been calculated to be either 1.3 or 2.0 corresponding to two or three dimensions, respectively [23]. Figure 4(b) (inset) shows a fitting of percolation equation for $\left(\mathrm{V}_{2} \mathrm{O}_{5}\right)_{1-\mathrm{x}}(\mathrm{GNP})_{\mathrm{x}}$ composites. The exponent $t$ was found to be about 1.4. This result confirms that the GNP nanoparticles are not located on the surface of the host material matrix particles, but it coordinated in the $\mathrm{V}_{2} \mathrm{O}_{5}$ crystal structure and the formation of graphene three dimensional network will enhancement.

\section{Cyclic voltammetry and discharge curve}

Figure 5(a) shows the schematic of the cell configuration of the $\mathrm{Mg}^{-} \mathrm{V}_{2} \mathrm{O}_{5}$ cells in this study. The activity of $\mathrm{V}_{2} \mathrm{O}_{5}$ and $\mathrm{V}_{2} \mathrm{O}_{5}$-graphene nanocomposite for hosting $\mathrm{Mg}^{+2}$ ions was evaluated using cyclic voltammetry $(\mathrm{CV})$ and galvanostatic discharge-charge techniques. Figure 5(b), shows the CV results obtained from 2.5 to $0 \mathrm{~V}$ using $\mathrm{V}_{2} \mathrm{O}_{5}$ and $\mathrm{V}_{2} \mathrm{O}_{5}$-graphene nanocomposite as a working electrode in a three-electrode cell employing magnesium metal as the counter and reference electrode at a scan rate of 0.05 $\mathrm{mV} \mathrm{s}^{-1}$. Although GNP succeeded to increase conductivity of $\mathrm{V}_{2} \mathrm{O}_{5}$, it failed to increase 

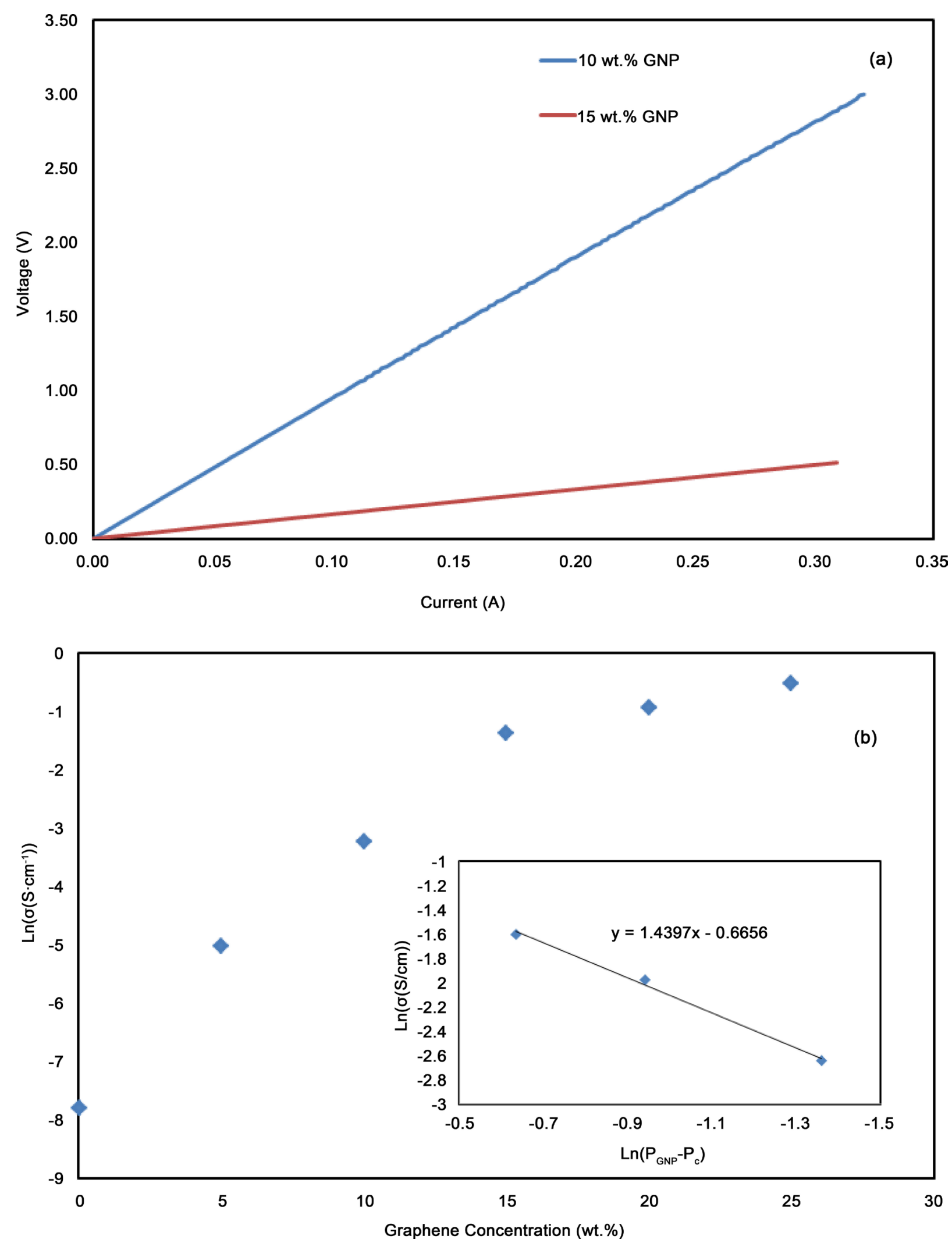

Figure 4. (a) I-V curves of $\left(\mathrm{V}_{2} \mathrm{O}_{5}\right)_{\mathrm{x}} /(\mathrm{GNP})_{1-\mathrm{x}}$ composites; (b) Variation of dc conductivity of $\left(\mathrm{V}_{2} \mathrm{O}_{5}\right)_{\mathrm{x}} /\left(\mathrm{GNP}_{1-\mathrm{x}}\right.$ composites at different grapheme concentrations 


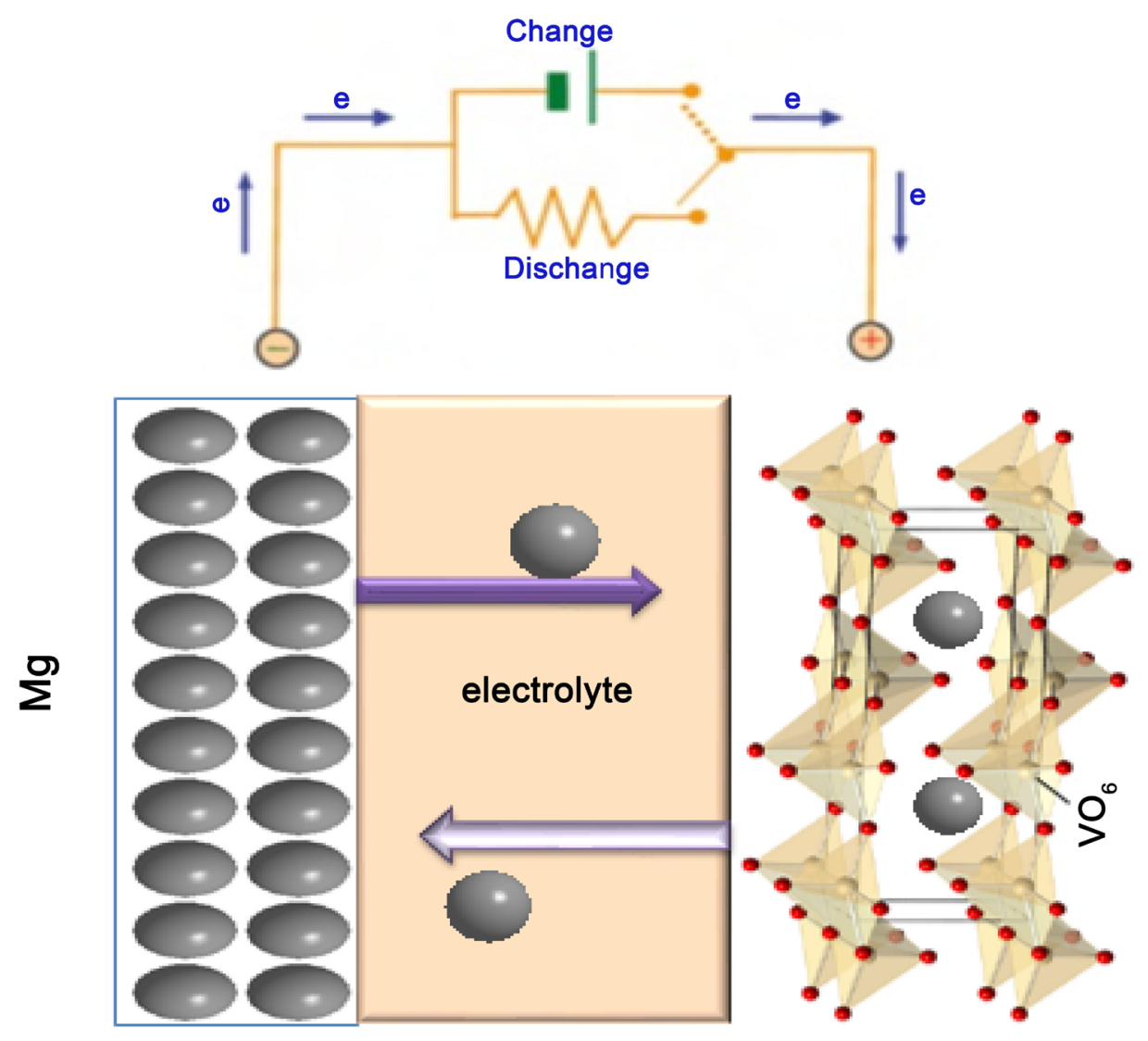

(a)

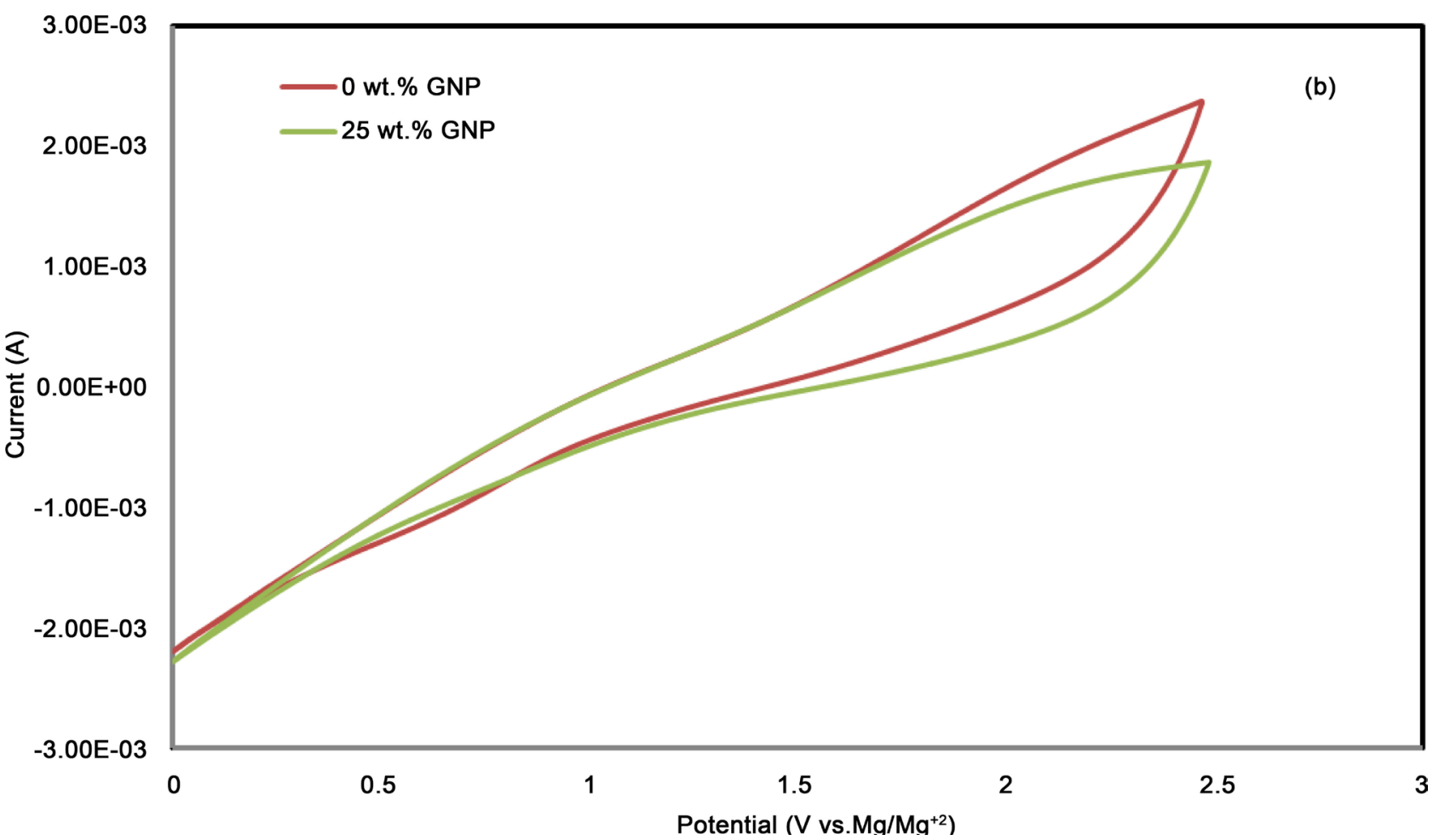

Figure 5. (a) Schematic illustrates $\mathrm{Mg}^{+2}$ insertion/extraction within $\mathrm{V}_{2} \mathrm{O}_{5}$; (b) Comparison of the $C V$ curves $\left(\right.$ at $5 \mathrm{mV} \cdot \mathrm{s}^{-1}$ ) for $\mathrm{V}_{2} \mathrm{O}_{5}$ and $\mathrm{V}_{2} \mathrm{O}_{5}$ /graphene nano-composite. 

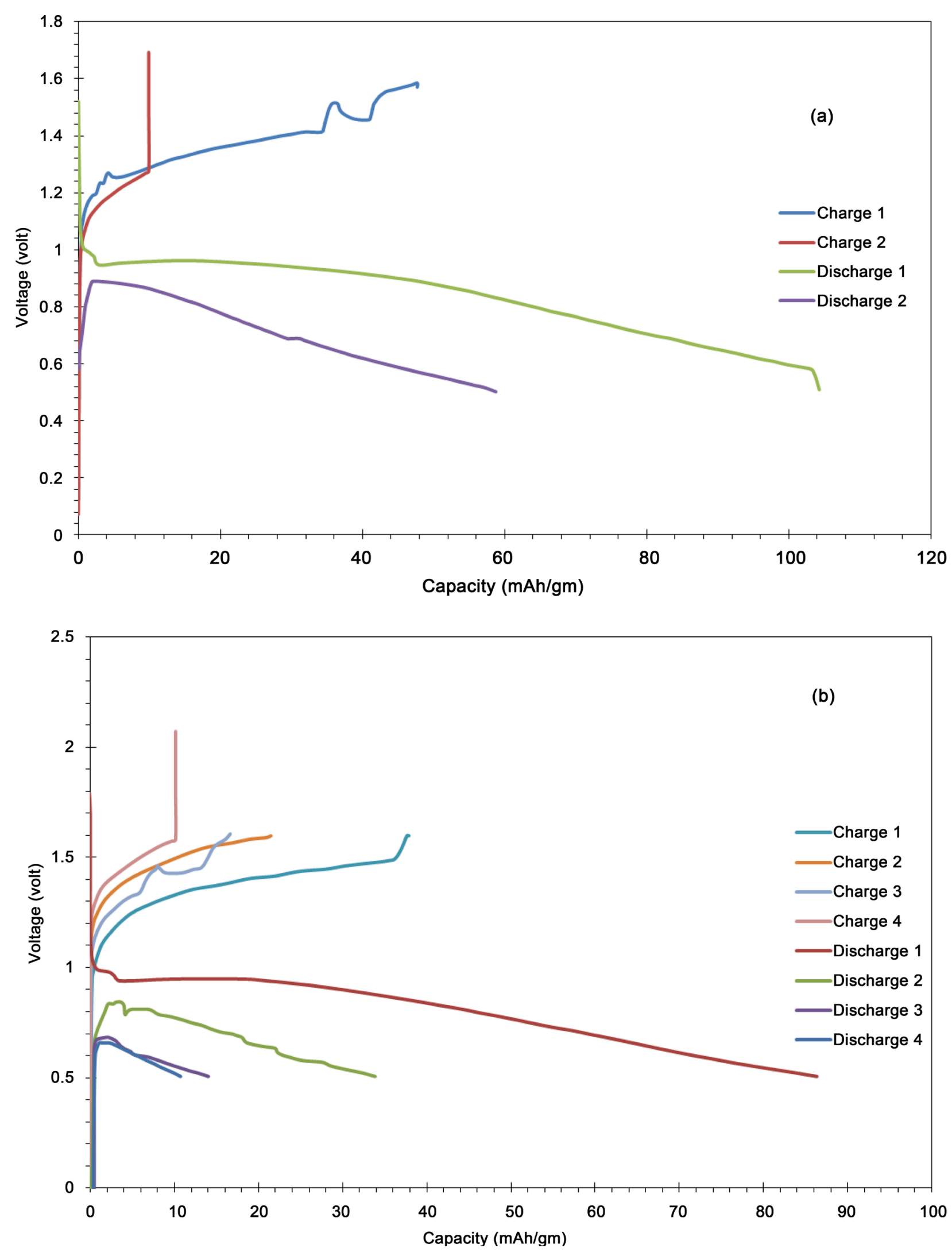

Figure 6. Discharge-charge profiles of (a) $\mathrm{V}_{2} \mathrm{O}_{5}$ (b) $\mathrm{V}_{2} \mathrm{O}_{5}$ /graphene nano-composite cathodic materials. 
the cathodic and anodic current density. This can be attributed to that the introduction of GNP in $\mathrm{V}_{2} \mathrm{O}_{5}$ using ball mill technique can perturb the (001) interlayer spacing of $\mathrm{V}_{2} \mathrm{O}_{5}$ and may be reduce intercalation rate. The perturbation in the interlayer spacing probably decreases the probability of $\mathrm{Mg}^{+2}$ insertion/extraction between interlayer spacing and hence decrease the specific capacity as we will see.

Figure 6(a) \& Figure 6(b) show discharge/charge profiles of $\mathrm{Mg} / \mathrm{V}_{2} \mathrm{O}_{5}$ and $\mathrm{Mg} /\left(\mathrm{V}_{2} \mathrm{O}_{5} / \mathrm{GNP}\right)$ coin cells, in which current density was fixed at $=40 \mu \mathrm{Acm}^{-1}$ and the cells were discharged to $0 \mathrm{~V}$ and charged to $1.6 \mathrm{~V}$. The initial discharge capacity of $\mathrm{Mg}$ / $\mathrm{V}_{2} \mathrm{O}_{5}$ and $\mathrm{Mg} /\left(\mathrm{V}_{2} \mathrm{O}_{5} / \mathrm{GNP}\right)$ coin cells are approximately 100 and $90 \mathrm{mAhg}^{-1}$, respectively. The combination of $\mathrm{V}_{2} \mathrm{O}_{5}$ with GNP decrease the discharge capacity compared to pure $\mathrm{V}_{2} \mathrm{O}_{5}$. We could not obtain more than 2 and 4 cycles for pure and graphitized $\mathrm{V}_{2} \mathrm{O}_{5}$, respectively. We think the structure property of $\mathrm{V}_{2} \mathrm{O}_{5}$ which give the advantage (001 large interlayer spacing $(\sim 11.53 \AA)$ ) of facile $\mathrm{Mg}^{+}$insertion/extraction was deformed after initial cycling. The intercalation of $\mathrm{Mg}^{+2}$ may perturb the bonding scheme of $\mathrm{V}_{2} \mathrm{O}_{5}$ and losses it this property.

\section{Conclusion}

In summary, $\mathrm{V}_{2} \mathrm{O}_{5} / \mathrm{GNP}$ cathode was synthesized by a ball mill method. The integration of $\mathrm{V}_{2} \mathrm{O}_{5}$ and graphene nanoparticles enhanced the electrical performances. This improved performance could be attributed to the formation of framework nanoscale electrode of $2 \mathrm{D}$ graphene decorated with well-dispersed $\mathrm{V}_{2} \mathrm{O}_{5}$ nanoparticle. Although GNP perturbed the (001) interlayer spacing hence, it failed to enhance the electrochemical performance. As-prepared $\mathrm{V}_{2} \mathrm{O}_{5}$ and $\mathrm{V}_{2} \mathrm{O}_{5} / \mathrm{GNP}$ cathodes can deliver a high capacity of 100 and $90 \mathrm{mAh} \cdot \mathrm{g}^{-1}$ respectively, which provides a new direction to explore cathode materials for rechargeable $\mathrm{Mg}$ batteries. Further extensive investigations are required, however, to raise the performance of the magnesium-based rechargeable cells to practical levels.

\section{References}

[1] Kouji, T., Yunpeng, G., Yukari, K., Takafumi, Y. and Hidenori, T. (2016) Rechargeable Mg Battery Cathode $\mathrm{TiS}_{3}$ with d-p Orbital Hybridized Electronic Structures. Applied Physics Express, 9, Article ID: 011801.

[2] Su, S.J., Huang, Z.G., NuLi, Y., Tuerxun, F., Yang, J. and Wang, J.L. (2015) A Novel Rechargeable Battery with a Magnesium Anode, a Titanium Dioxide Cathode, and a Magnesium Borohydride/Tetraglyme Electrolyte. Chemical Communications, 51, 2641-2644. http://dx.doi.org/10.1039/C4CC08774G

[3] Aurbach, D., Lu, Z., Schechter, A., Gofer, Y., Gizbar, H., Turgeman, R., Cohen, Y., Moshkovich, M. and Levi, E. (2000) Prototype Systems for Rechargeable Magnesium Batteries. Nature, 107, 724-727. http://dx.doi.org/10.1038/35037553

[4] Zhang, M., MacRae, A.C., Liu, H. and Meng, Y.S. (2016) Communication-Investigation of Anatase- $\mathrm{TiO}_{2}$ as an Efficient Electrode Material for Magnesium-Ion Batteries. Journal of the Electrochemical Society, 163, A2368-A2370. http://dx.doi.org/10.1149/2.1091610jes

[5] Tao, Z., Xu, L., Gou, X., Chen, J. and Yuan, H. (2004) $\mathrm{TiS}_{2}$ Nanotubes as the Cathode Materials of Mg-Ion Batteries. Chemical Communications, 18, 2080-2081. 
http://dx.doi.org/10.1039/b403855j

[6] Hsu, C.-J., Chou, C.-Y., Yang, C.-H., Lee, T.-C. and Chang, J.-K. (2015) $\mathrm{MoS}_{2} / \mathrm{Graphene}$ Cathodes for Reversibly Storing $\mathrm{Mg}^{2+}$ and $\mathrm{Mg}^{2+} / \mathrm{Li}^{+}$in Rechargeable Magnesium-Anode Batteries. Chemical Communications, 52, 1701-1704. http://dx.doi.org/10.1039/C5CC09407K

[7] Sheha, E. and Bassyouni, A. (2016) Structure, Thermal and Electrical Properties of Germanium Oxide/Graphene Nano-Composite Cathode for Magnesium. Energy and Environment Focus, 5, 1-6.

[8] Niya, Sa., Kinnibrugh, T.L., Wang, H., Gautam, G.S., Chapman, K.W., et al. (2016) Structural Evolution of Reversible Mg Insertion into a Bilayer Structure of $\mathrm{V}_{2} \mathrm{O}_{5} \cdot \mathrm{nH}_{2} \mathrm{O}$ Xerogel Material. Chemistry of Materials, 28, 2962-2969.

http://dx.doi.org/10.1021/acs.chemmater.6b00026

[9] Lu, W., Karina, A., Per, E.V., Ann, M.S. and Fride, V.-B. (2016) Sponge-Like Porous Manganese (II, III) Oxide as a Highly Efficient Cathode Material for Rechargeable Magnesium Ion Batteries. Chemistry of Materils, 28, 6459-6470.

http://dx.doi.org/10.1021/acs.chemmater.6b01016

[10] Laubach, S., Schmidt, P., Thipen, A., Fernandez-Madrigal, F., Wu, Q. and Jaegermann, W. (2007) Theoretical and Experimental Determination of the Electronic Structure of $\mathrm{V}_{2} \mathrm{O}_{5}$, Reduced $\mathrm{V}_{2} \mathrm{O}_{5-\mathrm{x}}$ and Sodium Intercalated $\mathrm{NaV}_{2} \mathrm{O}_{5}$. Chemical Physics, 9, 2564-2576.

[11] Su, D. and Wang, G. (2013) Single-Crystalline Bilayered $\mathrm{V}_{2} \mathrm{O}_{5}$ Nanobelts for High-Capacity Sodium-Ion Batteries. ACS Nano, 7, 11218-11226. http://dx.doi.org/10.1021/nn405014d

[12] Gershinsky, G., Yoo, H.D., Gofer, Y. and Aurbach, D. (2013) Electrochemical and Spectroscopic Analysis of $\mathrm{Mg}^{2+}$ Intercalation into Thin Film Electrodes of Layered Oxides: $\mathrm{V}_{2} \mathrm{O}_{5}$ and $\mathrm{MoO}_{3}$. Langmuir, 29, 10964-19672. http://dx.doi.org/10.1021/la402391f

[13] Chiku, M., Takeda, H., Matsumura, S., Higuchi, E. and Inoue, H. (2015) Amorphous Vanadium Oxide/Carbon Composite Positive Electrode for Rechargeable Aluminum Battery. ACS Applied Materials \& Interfaces, 7, 24385-24389. http://dx.doi.org/10.1021/acsami.5b06420

[14] Yu, R., Zhang, C., Meng, Q., Chen, Z., Liu, H. and Guo, Z. (2013) Facile Synthesis of Hierarchical Networks Composed of Highly Interconnected $\mathrm{V}_{2} \mathrm{O}_{5}$ Nanosheets Assembled on Carbon Nanotubes and Their Superior Lithium Storage Properties. ACS Applied Materials \& Interfaces, 5, 12394-12399. http://dx.doi.org/10.1021/am4033444

[15] Liu, H. and Yang, W. (2011) Ultralong Single Crystalline $\mathrm{V}_{2} \mathrm{O}_{5}$ Nanowire/Graphene Composite Fabricated by a Facile Green Approach and Its Lithium Storage Behavior. Energy \& Environmental Science, 4, 4000-4008. http://dx.doi.org/10.1039/c1ee01353j

[16] Du, X., Huang, G., Qin, Y. and Wang, L. (2015) Solvothermal Synthesis of GO/ $\mathrm{V}_{2} \mathrm{O}_{5}$ Composites as a Cathode Material for Rechargeable Magnesium Batteries. RSC Advances, 5, 76352-76355. http://dx.doi.org/10.1039/C5RA15284D

[17] Venkatesan, A., KrishnaChandar, N., Arjunan, S., Marimuthu, K.N., MohanKumar, R. and Jayavel, R. (2013) Structural, Morphological and Optical Properties of Highly Monodispersed PEG Capped $\mathrm{V}_{2} \mathrm{O}_{5}$ Nanoparticles Synthesized through a Non-Aqueous Route. Materials Letters, 91, 228-231. http://dx.doi.org/10.1016/j.matlet.2012.09.117

[18] Chen, D., Yi, R., Chen, S., Xu, T., Gordin, M.L., Lv, D. and Wang, D. (2014) Solvothermal Synthesis of $\mathrm{V}_{2} \mathrm{O}_{5} /$ Graphene Nanocomposites for High Performance Lithium Ion Batteries. Materials Science and Engineering: B, 185, 7-12. http://dx.doi.org/10.1016/j.mseb.2014.01.015

[19] Karteri, I., Karatas, S. and Yakuphanoglu, F. (2014) Electrical Characterization of Graphene 
Oxide and Organic Dielectric Layers Based on Thin Film Transistor. Applied Surface Science, 318, 74-78. http://dx.doi.org/10.1016/j.apsusc.2014.01.013

[20] Chand, N., Rai, N., Agrawal, S.L. and Patel, S.K. (2011) Morphology, Thermal, Electrical and Electrochemical Stability of Nano Aluminium-Oxide-Filled Polyvinyl Alcohol Composite gel Electrolyte. Bulletin of Materials Science, 34, 1297-1304.

http://dx.doi.org/10.1007/s12034-011-0318-7

[21] Gamal, R., Sheha, E., Shash, N. and El-Shaarawy, M.G. (2015) Effect of Tetraethylene Glycol Dimethyl Ether on Electrical, Structural and Thermal Properties of PVA-Based Polymer Electrolyte for Magnesium Battery. Acta Physica Polonica A. 127, 803-810.

http://dx.doi.org/10.12693/APhysPolA.127.803

[22] Fan, Y., Wang, L., Li, J., Li, J., Sun, S., Chen, F., Chen, L. and Jiang, W. (2010) Preparation and Electrical Properties of Graphene Nanosheet/ $\mathrm{Al}_{2} \mathrm{O}_{3}$ Composites. Capron, 48, 1743 1749. http://dx.doi.org/10.1016/j.carbon.2010.01.017

[23] Pang, H., Chen, T., Zhang, G., Zeng, B. and Li, Z.M. (2010) An Electrically Conducting Polymer/Graphene Composite with a Very Low Percolation Threshold. Materials Letters, 64, 2226-2229. http://dx.doi.org/10.1016/j.matlet.2010.07.001

Submit or recommend next manuscript to SCIRP and we will provide best service for you:

Accepting pre-submission inquiries through Email, Facebook, LinkedIn, Twitter, etc.

A wide selection of journals (inclusive of 9 subjects, more than 200 journals)

Providing 24-hour high-quality service

User-friendly online submission system

Fair and swift peer-review system

Efficient typesetting and proofreading procedure

Display of the result of downloads and visits, as well as the number of cited articles

Maximum dissemination of your research work

Submit your manuscript at: http://papersubmission.scirp.org/

Or contact graphene@scirp.org 